\title{
ENERGETIC EFFICIENCY OF SALIX VIMINALIS PLANTATION
}

\section{Olga ORYNYCZ, Artur CHODORSKI, Andrzej WASIAK}

Bialystok University of Technology, POLAND

E-mail of corresponding author: o.orynycz@pb.edu.pl

Keywords: willow, salix viminalis, EROEI, energetic efficiency

\begin{abstract}
Energetic efficiency, based on a version of EROEI indicator, of salix viminalis plantation is estimated for realistic tillage technology. For different plantation sizes, different sets of machines are selected for performing agro-technical operations. Obtained results are dependent upon plantation size, and characteristics of technical devices applied. Potential values of energetic efficiency are rather high, but it has to be taken into account that the study is confined to the limited number of operations corresponding to strictly agricultural operations. Addition of other steps in production system is supposed to decrease final values.
\end{abstract}

\section{INTRODUCTION}

Biomass became considered as an alternative source of energy that might replace fossil fuels (at least for some time). This idea results of two factors: first is expectation of sc. "oil peak" - that implies possible shortages of resources. and the second widely discussed climatic effects of use of the fossil fuels. Exploitation of biomass seems to mitigate the both threads mentioned. The energetic use of biomass various origins (both wild or planted) requires inputs of energy on various steps of production. Therefore, it is important that sum of the energy inputs, given to all steps of production, does not exceed final amount of energy obtained from biomass. The effects of biofuel use for sustainability of agriculture have been recently discussed by Wasiak (2016). The characteristic describing energetic efficiency of particular energy producing system under the name EROEI was introduced by Cleveland et al. (1984), Murphy at al. (2010), Murphy et al. (2011) and also Zhang and Colosi (2013). The later Authors indicated, however that various calculation procedures being used might cause discrepancies in results and cause ambiguities of interpretation. Various analyses concerning energetic use of biomass were also published (cf. Field et al. (2007), Mediavilla et al. (2013), Arodudu et al. (2014) and Liu (2017). Recently also Pickard (2014) discussed the applicability of the EROEI to situations of modern technology and introduced some modifications. The following formula was proposed for any system used to convert some material resources onto energy:

$$
E R O E I=\frac{E_{\text {out }}}{E_{\text {cr }}+\sum E_{\text {in }}+E_{\text {liq }}}
$$

where $E_{\text {out }}$ - is the energy obtained at the end (exit) of the system, $E_{c r}-$ is energy needed for creation of the system, $E_{l i q}-$ is energy needed for liquidation of that system. The $E_{\text {in }}$ denotes one of many possible inputs of energy needed for subsequent steps of converting the particular resource or byproduct finally leading to energy. Obviously the EROEI indicator is a dimensionless quantity.

This formula was used by Wasiak and Orynycz (2014) as well as Wasiak and Orynycz (2015) in formulation of the model for energetic effectiveness of agricultural subsystem being the part of biodiesel production system. In this case it was assumed that energetic efficiency indicator, $\varepsilon$, is computed for already existing system, liquidation of which is not planned within the period of consideration. Therefore, the formula assumes form: 


$$
\varepsilon=\frac{E_{\text {out }}}{\sum E_{\text {in }}}
$$

where meaning of symbols is the same as in Eq. 1.

The model is based on computation of contributions of energy consumption, by individual operations, $E_{i n}$. For each operation a partial energetic efficiency, $\varepsilon_{i}$, can be defined as ratio of final energy obtained in form of biofuel to the particular value of any individual contribution:

$$
\varepsilon_{i}=\frac{E_{\text {out }}}{E_{\text {in }}(i)}
$$

and therefore:

$$
\varepsilon^{-1}=\sum \varepsilon_{i}^{-1}
$$

This approach enables recognition of the effects of contributions of individual technological operations on the final energetic effectiveness of production systems.

Slightly different approach is being used in agricultural community. The procedure introduced by Anuszewski (1987) was used by several authors e.g. Dobek (2007), Grzybek (2011) and others. The approach of those authors mainly differs from EROEI by taking into account the contribution of human work energy consumption.

Willow (salix viminalis) is one of the most popular plants (especially in Poland) that is used for energetic purposes. Analyses based on empirical studies performed by several authors e.g. Kwaśniewski (2010), Stolarski et al. (2011), Stolarski et al. (2016) show rather low values of energetic effectiveness, but evidently dependent upon technological and natural factors. The methodology used in those works corresponds to mentioned earlier Anuszewski's approach. Similar approach is also applied by Gallagher and Murphy (2013) to computation of energy balance of willow converted to biogas indicating promising possibility of such technology. The work contains detailed analysis of energy consumption in agricultural operations on willow plantation.

The present work contains preliminary computations of energetic efficiency based on purely technical considerations.

\section{RESULTS AND DISCUSSION}

The scope of the work is confined to only agricultural operations. It will be extended by separate computations of other components of production system, like drying, transport, converting into a specific fuel (pellet, briquette, gaseous fuel, etc.). The fuel consumption is estimated on the basis of assumption $192 \mathrm{~g} / \mathrm{kWh}$, and corresponding technical data of individual machines. The estimated values are approximately in agreement with the data reported in the book of Lorencowicz (2012). Machines are arbitrarily chosen according to the size of plantation. Results of computations presented here concern plantation size equal one and one hundred hectares. In this case the use of including $66 \mathrm{KM}$ tractor KUBOTA M6040 was assumed. The choice of machines, as well as results of computation of consumed energy are shown in Table 1. It is seen that the most energy consuming operations are ploughing and cutting of crops. In the case of one-hectare planting of willow is assumed to be performed manually, and since we are interested in contributions in energy consumption only resulting from use of technical equipment, the energy contributed by human work is not taken into account. 
Table 1. Energy consumption by individual operations on 1 ha field

\begin{tabular}{|c|c|c|c|c|c|c|}
\hline \multirow[t]{2}{*}{ 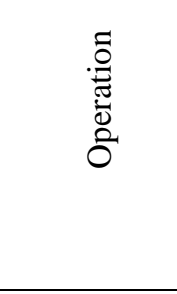 } & \multirow[t]{2}{*}{ 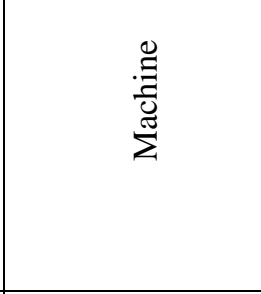 } & 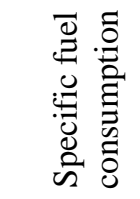 & 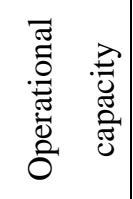 & 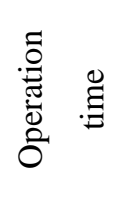 & 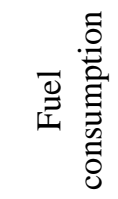 & 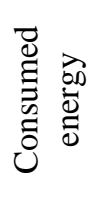 \\
\hline & & {$\left[\mathrm{dm}^{3} / \mathrm{h}\right]$} & [ha/h] & {$[\mathrm{h}]$} & {$\left[\mathrm{dm}^{3}\right]$} & [GJ] \\
\hline Planting & Manual *) & & & & & $*)$ \\
\hline Ploughing & $\begin{array}{l}\text { Plough Unia } \\
\text { Grudziądz 100B }\end{array}$ & 12 & 0.6 & 1.7 & 36.7 & 1.3 \\
\hline Cultivation & $\begin{array}{c}\text { Cultivator Unia } \\
\text { Grudziądz } \\
\text { ARESL/S } \\
\end{array}$ & 11 & 1.6 & 0.625 & 7.5 & 0.3 \\
\hline Spraying & $\begin{array}{c}\text { Sprayer } \\
\text { Pilmet 300LM }\end{array}$ & 8 & 4 & 0.25 & 2.75 & 0.1 \\
\hline $\begin{array}{c}\text { Fertilizatio } \\
n\end{array}$ & $\begin{array}{c}\text { Fertilizer } \\
\text { spreader SIPMA } \\
\text { RN } 410 \text { ANTEK }\end{array}$ & 8 & 3 & 0.33 & 2.67 & 0.1 \\
\hline Cutting & $\begin{array}{l}\text { Mower } \\
\text { Husqvarna } \\
\text { 555FXT }\end{array}$ & 1.36 & 0.024 & 41.7 & 333.33 & 11.7 \\
\hline & & TOT & & & & 13.5 \\
\hline
\end{tabular}

*) Human energy consumption for manual operations is not considered

The other choice of much more powerful machines is presented for 100 ha field. The choice, as well as computed working time, fuel consumption and resulting energy consumption are shown in Table 2. In this case the use of tractor 186 KM FENDT 718 VARIO was assumed. Obviously, energy consumption in all individual operations is higher than in the case of one-hectare field. In the case of large field two variants are considered. The first is mechanical planting of willow cuttings, and the second performing this operation manually. The energy consumption for the first case is estimated basing on operation time and fuel consumption, while for the second, the energy of human work is omitted. Results of energy consumption for both cases are reported in the Table 2. The column "Consumed energy" is split into two columns correspondingly containing data for the cases of mechanical and manual planting.

Agricultural operations are frequently accompanied with transport of various materials, and equipment. It can be transport of fertilizers, crop protection means as well as seedlings, etc. Practically, it concerns each operation. Such transport obviously consumes some energy, and should be included into calculations of energetic effectiveness. In the present work, this contribution is intentionally omitted in all operations, because transport energy consumption will be calculated for all operations as separate component.

The energy obtained from plantation is computed basing on the yield and low caloric value of final woody biofuel (pellet, briquette) in normal combustion (19 MJ/Mg i.e. $19 \mathrm{MJ}$ per one metric ton). 
Table 2. Energy consumption by individual operations on 100 ha field

\begin{tabular}{|c|c|c|c|c|c|c|c|}
\hline \multirow{3}{*}{ 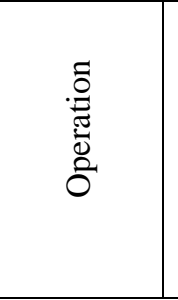 } & \multirow{3}{*}{$\begin{array}{l}\stackrel{0}{\Xi} \\
\stackrel{\Xi}{\Xi} \\
\Sigma\end{array}$} & \multirow{2}{*}{ 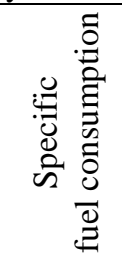 } & \multirow[b]{2}{*}{ 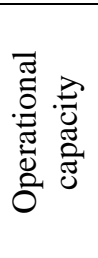 } & \multirow{2}{*}{ 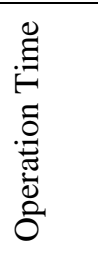 } & \multirow{2}{*}{ 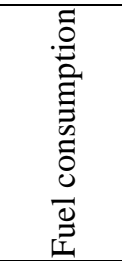 } & \multicolumn{2}{|c|}{ Consumed energy } \\
\hline & & & & & & 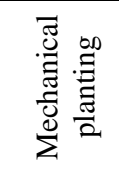 & 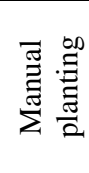 \\
\hline & & {$\left[\mathrm{dm}^{3} / \mathrm{h}\right]$} & [ha/h] & [h] & {$\left[\mathrm{dm}^{3}\right]$} & {$[\mathrm{GJ}]$} & {$[\mathrm{GJ}]$} \\
\hline Planting & $\begin{array}{c}\text { Planting } \\
\text { machine } \\
\text { SPAPPERI } \\
\text { TP }\end{array}$ & 12 & 0.36 & 277.8 & 3333.3 & 116.7 & $*)$ \\
\hline Ploughing & Plough & 22.5 & 1.8 & 55.6 & 1250 & 43.8 & 43.8 \\
\hline Cultivation & \begin{tabular}{|c} 
Cultivator \\
Agro Masz \\
$5.6 \mathrm{~m}$ \\
\end{tabular} & 21 & 2.4 & 41.7 & 875 & 30.7 & 30.7 \\
\hline Spraying & \begin{tabular}{|c} 
Sprayer \\
Pilmet \\
EuropaXL \\
30001 \\
\end{tabular} & 12 & 10 & 10 & 120 & 4.2 & 4.2 \\
\hline Fertilization & $\begin{array}{c}\text { Fertilizer } \\
\text { spreader } \\
\text { AMAZON } \\
\text { E ZA-M } \\
\text { ultra } \\
\end{array}$ & 14 & 14 & 7.7 & 100 & 3.5 & 3.5 \\
\hline Cutting & \begin{tabular}{|c|} 
Forage \\
harvester \\
Claas 940
\end{tabular} & 55 & 2.4 & 41.7 & 2291.6 & 80.3 & 80.3 \\
\hline \multicolumn{6}{|c|}{ TOTAL } & 279.2 & 162.5 \\
\hline
\end{tabular}

*) Human energy consumption for manual operations is not considered

Finally energetic efficiency for this step of production system is obtained by division of the energy yield from obtained solid biofuel by the energy consumption.

As for the energy yield two values are considered as lower and upper limits of values usually obtained in practice, also in both cases of energy yield the values of energy efficiency are reported in two columns for mechanical and manual planting. It should be noted that, as mentioned earlier, mechanical planting for one-hectare field was not considered. The obtained results are rather high, and very different for small and big plantation. The later values might result of not good choice of devices used in small plantation (too much fuel consuming, too small operational capacity - especially for chosen mower).

Table 3. Comparison of energetic efficiency, $\varepsilon$, for 1 ha and 100 ha fields treated with various machines

\begin{tabular}{|c|c|c|c|c|}
\hline \multirow{2}{*}{$\begin{array}{c}\text { Plantation } \\
\text { size } \\
{[\mathrm{ha}]}\end{array}$} & \multicolumn{2}{|c|}{ Energy yield 300 [GJ/ha] } & \multicolumn{2}{c|}{ Energy yield 580 [GJ/ha] } \\
\cline { 2 - 5 } & Mechanical planting & Manual planting *) & Mechanical planting & Manual planting *) \\
\hline 1 & - & 22.22 & - & 42.96 \\
\hline 100 & 107.5 & 207.7 & 207.7 & 356.9 \\
\hline
\end{tabular}

*) Human energy consumption for manual operations is not considered

The obtained values seem to be higher than those reported by other Authors, but it has to be recognized, that those are values of partial energetic efficiency (computed according 
to Eq. 3), in which the only part of production system is concerned. Operations like watering the fields, transportation of goods and equipment between and inside of fields, drying of crops, pelletizing, etc. are not considered, and those operations surely will decrease the final energetic effectiveness of the whole production system. This study also does not consider indirect energy consumption (embodied energy), which also causes a decrease of energetic efficiency. All the omitted factors will be the subject of further studies.

\section{CONCLUSIONS}

Presented results of preliminary study show that energetic efficiency of willow plantation may strongly be affected by the choice of equipment used for performing agro-technical operations. It also depends upon size of plantation in that sense that it may be difficult to optimize choice of equipment for particular plantations areas. The resulting values of energetic efficiency are varying between about 20 and about 360 depending on size of plantation and choice of operating equipment. Those values appear to be rather high as compared to the results presented in the literature. The main goal of this work is, however, to recognize the role of subsequent steps of production in forming final energetic efficiency of production system. Taking into account Eq. 4 it is possible to predict that each subsequent step will decrease the total efficiency. It is also predictable, that the less efficient step will mostly affect the final result. Consequently, establishing individual contributions of subsequent steps will enable looking for those components of production system that require major improvements. In presented cases, as the most energy consuming appear operations like ploughing, mechanical planting or harvesting. The operations like: transportation of goods to the fields, watering, transportation of crops, etc. will be the subject of subsequent works. It also seems that improvement in technology of energetic exploitation of biomass may be the important step onto achieving higher energetic efficiency of the biomass derived fuels. It might be expected that direct combustion is not mostly effective use of willow biomass - what possibly can be improved by changing the technology of obtaining other than solid fuels from this biomass.

\section{ACKNOWLEDGMENT}

The research has been performed under financial support from Bialystok University of Technology. Statutory Research Project S/WZ/1/2015.

Authors are very much indebted to prof. Edmund Lorencowicz for valuable discussion.

\section{REFERENCES}

Anuszewski, R. (1987). Metoda oceny energochłonności produktów rolniczych. Zagad. Ekon. Rol., 4, p. $16-26$.

Arodudu, O., Ibrahim, E., Voinov, A., \& Duren, I. (2014). Exploring bioenergy potentials of built-up areas based on NEG-EROEI indicators. Ecological Indicators, 47, p. 67-79.

Cleveland, C. J., Costanza, R., Hall, C. A., \& Kaufmann, R. (1984). Energy and the United States economy: a biophysical perspective. Science, 225, p. 890-897.

Dobek, T. K. (2007). Ocena efektywności ekonomicznej i energetycznej produkcji pszenicy ozimej i rzepaku ozimego wykorzystanych do produkcji biopaliw. Inżynieria Rolnicza, 6, p. 41-48.

Field, C. B., Campbell, J. E., \& Lobell, D. B. (2008). Biomass energy: the scale of the potential resource. Trends in Ecology and Evolution, 23, p. 65-72. 
Gallagher, C., Murphy, J. D. (2013). Is it better to produce biomethane via thermochemical or biological routes? An energy balance perspective. Biofuels. Bioprod. Bioref., 7, p. 273-281.

Grzybek, A. (2011). Sprawozdanie merytoryczne z wykonania projektu: Modelowanie energetycznego wykorzystania biomasy. Instytut Technologiczno-Przyrodniczy ITP., PL0073.

Kwaśniewski, D. (2010). Efektywność energetyczna produkcji biomasy z rocznej wierzby. Inżynieria Rolnicza, 1, p. 289-294.

Liu, W., Wang, J., Richard T. L., Hartley D. S., Spatari, S., \& Volk, T. A. (2017). Economic and life cycle assessments of biomass utilization for bioenergy products. Biofuels. Bioprod. Bioref., 11, p. 633647.

Lorencowicz, E. (2012). Poradnik użytkownika techniki rolniczej w tabelach, (Handbook for the user of agrotechnology). Agencja Promocji Rolnictwa i Agrobiznesu, Bydgoszcz.

Mediavilla, M., deCastro C., Capellán I., Miguel L. J., Arto, I., \& Frechoso, F. (2013). The transition towards renewable energies: Physical limits and temporal conditions. Energy Policy, 52, p. 297-311.

Murphy, D. J., Hall, C. A. (2010). Energy return on investment, peak oil, and the end of economic growth. Ann. N.Y. Acad. Sci. 1219, p. 52-72.

Murphy, D. J., Hall, C. A. S., Dale, M., \& Cleveland, C. (2011). Order from Chaos: A preliminary protocol for determining the EROEI of fuels. Sustainability, 3, p. 1888-1907.

Pickard, W. F. (2014). Energy Return on Energy Invested (EROI): A quintessential but possibly inadequate metric for sustainability in a solar-powered world? Proceedings of the IEEE, 102, p. 11181122 .

Stolarski, M., Szczukowski, S., \& Tworkowski, J. (2011). Efektywność energetyczna produkcji biomasy wierzby w systemie eko-salix. Fragm. Agron., 28, p. 62-69.

Stolarski, M. J., Krzyżaniak, M., Tworkowski, J., Szczukowski, S., \& Niksa, D. (2016). Analysis of the energy efficiency of short rotation woody crops biomass as affected by different methods of soil enrichment. Energy, 113, p. 748-761.

Wasiak, A., Orynycz, O. (2014). Formulation of a model for energetic efficiency of agricultural subsystem of biofuel production. IEEE International Energy Conference, p. 1333-1337.

Wasiak, A., Orynycz, O. (2015). The effects of energy contributions into subsidiary processes on energetic efficiency of biomass plantation supplying biofuel production system. Agriculture and Agricultural Science Procedia, 7, p. 292-300.

Wasiak, A. (2016). The effect of biofuel production on sustainability of agriculture. Biological System: Open Access, 5, p. 171-178.

Zhang, Y., Colosi, L. M. (2013). Practical ambiguities during calculation of energy ratios and their impacts on lifecycle assessment calculations. Energy Policy, 57, p. 630-633. 